\title{
PROMOSI KESEHATAN DALAM MENINGKATKAN PENGETAHUAN DAN SIKAP DETEKSI DINI KANKER PAYUDARA DENGAN METODE SADARI PADA IBU-IBU ANGGOTA 'AISYIYAH CABANG BANGUNTAPAN UTARA BANTUL
}

\author{
HEALTH PROMOTION IN IMPROVING \\ KNOWLEDGE AND ATTITUDE EARLY DETECTION OF BREAST CANCER \\ WITH THE MOTHER MOTHER BSE MEMBERS 'AISYIYAH NORTH BRANCH \\ BANGUNTAPAN BANTUL
}

\author{
Ismarwati \\ Program studi DIII Kebidanan, Fakultas Ilmu Kesehatan, Universitas 'Aisyiyah \\ Yogyakarta \\ Email : Ismarwt@gmail.com
}

\begin{abstract}
ABSTRAK
Masalah kesehatan pada organ tubuh yang paling vital pada perempuan yaitu terjadinya kanker payudara. Kegagalan penemuan secara dini kanker payudara dapat terjadi karena kurangnya pengetahuan oleh masyarakat. Padahal penemuan secara dini dapat dilakukan dengan mudah yaitu dengan metode pemeriksaan payudara sendiri (SADARI). Penelitian betujuan untuk mengetahui pengaruh promosi kesehatan tentang kanker payudara terhadap pengetahuan dan sikap deteksi dini kanker payudara dengan metode SADARI pada ibu-ibu anggota 'Aisyiyah Cabang Banguntapan, Kecamatan Banguntapan, Bantul. Penelitian kuantitatif ini dengan rancangan eksperimen menggunakan pre eksperimental design dengan metode one group pretest-postest design. Responden penelitian adalah Ibu-Ibu anggota 'Aisyiyah Cabang Banguntapan Utara, Kecamatan Banguntapan Bantul.Teknik pengambilan sampel dilakukan dengan Simple Random Sampling dengan jumlah sampel 22 orang. Analisa data dengan menggunakan Paired t-test. Hasil penelitian ini didaptkan 68,18\% berusia reproduksi yaitu di bawah 35 tahun, 77,27\% berpendidikan tinggi, dan 63,63\% tidak bekerja. Simpulannya ada pengaruh yang signifikan pada pelaksanaan promosi kesehatan dalam mempengaruhi pengetahuan dan sikap tentang deteksi dini kanker payudara dengan metode SADARI dengan nilai $p<0,05$. Disarankan masyarakat dapat melakukan pemeriksaan SADARI secara rutin.
\end{abstract}

Kata kunci : Promosi kesehatn, deteksi,sadari, pengetahuan, sikap

\begin{abstract}
Breast cancer is one of serious health problems for women on their vital organ. The failure to have an early detection of breast cancer is due to the low knowledge of the society regarding to this disease. Meanwhile, the early detection can be done easily with Breast Self-Exam (BSE). This research aims at finding out better use effect of health promotion on breast cancer better use the knowledge and attitude for early breast cancer detection with BSE method among the female members of Branch office of Aisyiyah, Banguntapan, Kecamatan Banguntapan, Bantul. This research was using quantitative method with experimental plan of one group pretest-posttest design. The respondent was the 22 female members of Banguntapan Branch office of Aisyiyah, Bantul. The sampling technique used simple random sampling. Data analysis technique used Paired T-test. The conclusion of this study showed that there was a significant influence on the implementation of health promotion on breast cancer toward the knowledge and attitude for early breast cancer detection with BSE method with the score of $p<0,05$. Regular BSE was recommended to the society.
\end{abstract}

Keywords: health promotion, detection, BSE, knowledge, attitude. 


\section{PENDAHULUAN}

Kanker adalah salah satu penyakit tidak menular yang bisa menyerang jaringan dalam berbagai organ tubuh termasuk organ reproduksi wanita seperti, payudara, rahim, indung telur, dan vagina (Mardiana, 2004). Menurut Mumpuni (2013) kanker payudara (Carcinoma Mammae) adalah suatu penyakit ketika sel-sel ganas terjadi pertumbuhan berlebihan dari jaringan payudara. Kanker payudara merupakan salah satu jenis kanker yang paling sering ditemukan dan penyebab utama kematian pada wanita (Depkes RI, 2009). Data dari Departemen Kesehatan (2012), menyebutkan prevalensi kanker payudara mencapai 4,3 banding 1.000 orang penderita kanker, data sebelumnya menyebutkan prevalensi hanya 1 banding 1.000 orang, angka penderita kanker payudara terus meningkat. Sutjipto (2013), dokter spesialis bedah kanker Rumah Sakit Kanker Dharmais, menyatakan saat ini penderita kanker payudara di Indonesia mencapai 100 dari 100.000 penduduk, sekitar $60-70 \%$ dari penderita tersebut datang pada stadium tiga yang kondisinya terlihat semakin parah (Depkes, 2013). Berdasarkan data Sistem Informasi Rumah Sakit (SIRS) tahun 2009, kanker payudara menempati urutan pertama pada pasien rawat inap di seluruh rumah sakit di Indonesia, yaitu sebanyak 21,69\% (Rasjidi, 2009).

Penderita kanker payudara yang datang di tiga rumah sakit Yogyakarta bagian bedah (RS Sardjito, Panti Rapih dan RS Patmasuri) sebagian besar pada stadium III (33,86\%) merupakan stadium lanjut lokal. Secara keseluruhan kasus stadium III sebanyak $48,26 \%$, sedangkan stadium IV didapatkan pada $7,1 \%$ penderita. Dari kasus tersebut banyak penderita yang tidak mengetahui secara dini dari tanda-tanda kanker payudara (Andaryanto, 2007). Berdasarkan sumber Dinkes Kabupaten Bantul tahun 2013 terdapat 34\% penderita kanker payudara dengan kasus baru dan kasus lama 63,31\% diantaranya paling banyak pada usia 20-44 tahun yaitu $33,85 \%$ penderita kanker payudara dengan kasus baru.

Kegagalan penemuan secara dini kanker payudara dapat terjadi karena kurangnya pengetahuan atau informasi yang didapatkan oleh masyarakat. Padahal penemuan secara dini dapat dilakukan dengan mudah yaitu dengan metode pemeriksaan payudara sendiri (Sadari). Metode Sadari ternyata belum tersosialisasikan dengan baik sehingga banyak masyarakat yang belum mengetahui metode Sadari tersebut.

Berdasarkan penelitian (Ismarwati, 2011 dan 2013) bahwa promosi kesehatan tentang deteksi dini kanker serviks dapat meningkatkan pengetahuan dan sikap tentang kanker serviks dan deteksi dini pada ibu-ibu anggota pengajian

Dinas Kesehatan melalui Puskesmas sudah memiliki program promosi kesehatan termasuk didalamnya adalah materi mengenai kesehatan reproduksi. Tetapi promosi kesehatan yang dilakukan masih bersifat umum belum spesifik dan belum ditindaklanjuti dengan tindakan 
konkrit seperti deteksi dini kanker payudara dengan metode Sadari. Sasaran kegiatan promosi kesehatan tidak hanya terbatas pada masyarakat umum tetapi juga dapat dilaksanakan pada kelompok-kelompok yang ada di masyarakat seperti forum ibu-ibu PKK, Majelis Ta'lim maupun Pengajian.

\section{METODE PENELITIAN}

Rancangan Penelitian ini menggunakan metode quasi

\section{HASIL DAN PEMBAHASAN}

\section{Hasil Penelitian}

\section{Karakteristik responden}

Responden penelitian ini adalah ibuibu anggota 'Aisyiyah Cabang Banguntapan Utara, Kecamatan Banguntapan, Bantul. Jumlah sampel sebanyak 22 orang. Pada Tabel 4.1 di jelaskan terkait dengan karakteristik responden. Karakteristik pada penelitian ini yaitu ibu-ibu anggota 'Aisyiyah Cabang Banguntapan Utara, Kecamatan Banguntapan, Bantul $68,18 \%$ berusia reproduksi yaitu di bawah 35 tahun, $77,27 \%$ berpendidikan tinggi, dan $63,63 \%$ tidak bekerja.

\section{Analisis Hasil Penelitian}

Table 4.2 Distribusi frekuensi variabel penelitian

\begin{tabular}{lllll}
\hline $\begin{array}{l}\mathrm{N} \\
\mathrm{o}\end{array}$ & Variabel & Kategori & $\begin{array}{l}\text { Frek } \\
\text { uensi }\end{array}$ & $\begin{array}{l}\text { Presentas } \\
\mathrm{e}(\%)\end{array}$ \\
\hline 1 & $\begin{array}{l}\text { Pengetahua } \\
\text { n saat pre }\end{array}$ & $\begin{array}{l}\text { Sangat } \\
\text { kurang }\end{array}$ & 0 & 0 \\
& test & Kurang & 4 & 18,18 \\
& & Cukup & 5 & 22,72 \\
& & Baik & 13 & 50,09 \\
2 & Pengetahua & Sangat & 0 & 0 \\
& n saat post & kurang & &
\end{tabular}

eksperimen. Kegiatan quasi eksperimen ini dengan tujuan untuk mengetahui suatu gejala atau pengaruh yang timbul sebagai akibat dari adanya perlakuan (Notoatmodjo, 2005). Rancangan eksperimen yang digunakan dalam penelitian ini menggunakan pre eksperimental design dengan metode one group pretest-postest design. Rancangan ini dilakukan observasi pertama (pretest) dan observasi ke dua setelah perlakuan (Notoatmodjo, 2012).

\begin{tabular}{|c|c|c|c|c|}
\hline $\begin{array}{l}\mathrm{N} \\
\mathrm{O}\end{array}$ & Variabel & Kategori & $\begin{array}{l}\text { Frek } \\
\text { uensi }\end{array}$ & $\begin{array}{l}\text { Presentas } \\
\text { e }(\%)\end{array}$ \\
\hline & test & Kurang & 0 & 0 \\
\hline & & Cukup & 7 & 31,81 \\
\hline & & Baik & 15 & 68,18 \\
\hline \multirow[t]{4}{*}{3} & $\begin{array}{l}\text { Sikap saat } \\
\text { pre test }\end{array}$ & $\begin{array}{l}\text { Sangat } \\
\text { buruk }\end{array}$ & 0 & 0 \\
\hline & & Buruk & 19 & 86,36 \\
\hline & & Cukup & 3 & 13,63 \\
\hline & & Baik & 0 & 0 \\
\hline \multirow[t]{4}{*}{4} & $\begin{array}{l}\text { Sikap saat } \\
\text { post test }\end{array}$ & $\begin{array}{l}\text { Sangat } \\
\text { buruk }\end{array}$ & 0 & 0 \\
\hline & & Buruk & 9 & 40,90 \\
\hline & & Cukup & 13 & 59,09 \\
\hline & & Baik & 0 & 0 \\
\hline
\end{tabular}

\section{Analisis Hasil Pengetahuan}

Uji statistik yang digunakan pada penelitian ini adalah adalah pair t test dengan confident interval (CI) $95 \%$. Karena probabilitas (sig) 0,011<0,05 maka $\mathrm{H}_{\mathrm{o}}$ ditolak yang artinya ada pengaruh yang signifikan pada pelaksanaan promosi kesehatan dalam mempengaruhi pengetahuan ibu-ibu 'Aisyiyah Cabang Banguntapan Utara tentang deteksi dini kanker payudara dengan metode SADARI.

\section{Analisis Hasil Pengetahuan}


Uji statistik yang digunakan pada penelitian ini adalah adalah pair $t$ test dengan confident interval (CI) $95 \%$. Karena probabilitas (sig) $0,030<0,05$ maka $\mathrm{H}_{\mathrm{o}}$ ditolak yang artinya ada pengaruh yang signifikan pada pelaksanaan promosi kesehatan dalam mempengaruhi sikap ibu-ibu 'Aisyiyah Cabang Banguntapan Utara tentang deteksi dini kanker payudara dengan metode SADARI.

\section{Pembahasan}

Pada penelitian ini didapatkan hasil bahwa ibu-ibu anggota 'Aisyiyah Cabang Banguntapan Utara, Kecamatan Banguntapan, Bantul $77,27 \%$ berpendidikan tinggi. Dyson, et al. (2005), bahwa ibu yang memiliki pendidikan tinggi akan mudah menerima informasi. Informasi yang diterima dengan baik akan meningkatkan pengetahuan orang yang menerima informasi. Informasi akan mudah diterima oleh ibu apabila diberikan dengan tepat. Hal ini sesuai penelitian Oberhelman, et al. (2015), pemberian informasi yang komprehensif dan tepat juga memiliki pengaruh terhadap pengetahuan yang pada akhirnya akan mempengaruhi sikap.

\section{Pengaruh promosi kesehatan kanker payudara dengan metode SADARI terhadap pengetahuan deteksi dini kanker payudara}

Pengetahuan (knowladge) menurut Simons dan Gottlieb (1995) adalah pengenalan terhadap kenyataan, prinsip dan arti suatu obyek. Pengetahuan dapat diberikan melalui berbagai cara baik melalui pendidikan yang terstruktur maupun tidak terstruktur seperti pengalaman sehari-hari seperti membaca, mendengar informasi dari media cetak maupun elektronik. Upaya yang di lakukan dalam meningkatkan pengetahuan salah satunya adalah dengan kegiatan promosi. Penelitian (Ismarwati, 2011 dan 2013) bahwa promosi kesehatan tentang deteksi dini kanker serviks dapat meningkatkan pengetahuan dan sikap tentang kanker serviks dan deteksi dini pada ibu-ibu anggota pengajian.

Promosi kesehatan menurut WHO merupakan proses menyupayakan individu-individu dan masyarakat untuk meningkatkan kemampuan mengendalikan faktor-faktor kesehatan sehingga bisa meningkatkan kesehatan nya. Pelaksanaan promosi kesehatan tentang kanker payudara yang dilakukan pada penelitian ini yaitu dengan metode SADARI yang dilakukan pre test dan post test untuk menggali pengetahuan ibu, memiliki nilai probabilitas (sig) $0,011<0,05$ maka Ho ditolak yang artinya ada pengaruh yang signifikan pada pelaksanaan promosi kesehatan dengan metode SADAR dalam mempengaruhi pengetahuan ibu-ibu 'Aisyiyah Cabang Banguntapan Utara tentang deteksi dini kanker payudara. Hal ini sesuai dengan yang telah dilakukan Sugandi (2015), bahwa promosi kesehatan yang dilakukan oleh tenaga kesehatan berpengaruh terhadap pengetahuan seseorang.

\section{Pengaruh promosi kesehatan kanker payudara dengan metode SADARI terhadap sikap deteksi dini kanker payudara}

Bagian hasil berisi secara urut dari yang umum kearah khusus dan logis dengan uraian, tabel, dan ilustrasi. Ditekankan pada hasil observasi yang penting tanpa interpretasi dari penulis. Gambar dan tabel harus diberi judul dan, jika bersumber dari publikasi terdahulu, harus mendapat persetujuan dari penulisnya. 
Bagian pembahasan berisi interpretasi dan analisis yang komprehensif dari hasil penelitian yang diperoleh dan dikaitkan dengan hasil-hasil yang pernah dilaporkan.

Sikap menurut Secord dan Baackman (cit Azwar, 2007) mendefinisikan sikap adalah keteraturan dalam hal perasaan (afeksi), pemikiran (kognisi), dan predisposisi tindakan (konasi) seseorang terhadap sesuatu yang ada dilingkungannya. Sikap adalah suatu perasaan agak konstan yang diarahkan terhadap suatu objek dan melekat dalam struktur pada sikap adalah evaluasi (Green \& Kreuter, 1991). Gagné, et al. (2005), menambahan bahwa sikap merupakan suatu keadaan internal yang mempengaruhi seseorang dalam menentukan tindakan terhadap beberapa obyek, pribadi, dan peristiwa. Penelitian (Ismarwati, 2011 dan 2013) bahwa promosi kesehatan tentang deteksi dini kanker serviks dapat meningkatkan pengetahuan dan sikap tentang kanker serviks dan deteksi dini pada ibu-ibu anggota pengajian. Hal ini sesuai dengan hasil penelitian ini bahwa ada pengaruh yang signifikan pada pelaksanaan promosi kesehatan dalam mempengaruhi sikap ibu-ibu 'Aisyiyah Cabang Banguntapan Utara tentang deteksi dini kanker payudara dengan metode SADARI. Hal ini di tunjukkan pada tabel 4.4 nilai pair ttest menunjukkan bahwa nilai $p$ $0,030<0,05$.

Penelitian ini sejalan dengan penelitian yang dilakukan oleh Santosa, Taviv, \& Mayasari (2014), bahwa promosi kesehatan dapat meningkatkan pengetahuan, sikap dan kesadaran masyarakat terhadap kesehatan. Pada penelitian ini, ibu-ibu yang telah diberikan promosi kesehatan terjadi peningkatan pengetahuan. Berdasarkan penelitian Kornides \& Kitsantas (2014), bahwa pemberian informasi dengan cara yang tepat akan meningkatkan pengetahuan ibu.

\section{SIMPULAN}

Ada pengaruh yang signifikan pada pelaksanaan promosi kesehatan dengan metode SADAR dalam mempengaruhi pengetahuan ibu-ibu 'Aisyiyah Cabang Banguntapan Utara tentang deteksi dini kanker payudara. Ada pengaruh yang signifikan pada pelaksanaan promosi kesehatan dengan metode SADAR dalam mempengaruhi sikap ibu-ibu 'Aisyiyah Cabang Banguntapan Utara tentang deteksi dini kanker payudara.

\section{DAFTAR PUSTAKA}

Azwar, S. 2007. Sikap Manusia Teori dan Pengukurannya. Pustaka Pelajar:Yogyakarta

Departemen Kesehatan RI, 2009.Buku Saku Pencegahan Kanker Leher Rahim \& Kanker Payudara. Depkes RI, Jakarta.

Dyson, L., McCormick, F., \& Renfrew, M.J. (2005) Interventions for promoting the initiation of breasfeeding (Review),

Cochrane Database of Systematic, Issue 2.

DOI:10.1002/14651858. CD001688.pub2

Gagné, R.M., Brigg, J.L., dan Wager, W.W. (2005) Principles of instructional design, Available at: http://onlinelibrary.wiley.co m/doi/10.1002/pfi.41404402 11/abstract. 
Green, Lawrence W., Marchel W

Kreuter. 1999. Health

Promoting Planning an educational and environmental aproach. Second Edition. Mayfield Publishing Company: Mountain View.

Ismarwati, 2012. Promosi Kesehatan dalam meningkatkan pengetahuan, sikap dan perilaku deteksi dini kanker serviks di Ibu-Ibu anggota pengajian. Jurnal Kedokteran (BKM) UGM

,2014. Promosi Kesehatan dalam meningkatkan pengetahuan, sikap dan perilaku deteksi dini kanker serviks di Banguntapan. Proceding Seminar Nasional stikes 'Aisyiyah Yogyakarta.

Karundeng, F.F. et al., 2015. Pengaruh Promosi Kesehatan Reproduksi Remaja Terhadap Pengetahuan Dan Sikap Siswa SMP Negeri 08 Bitung. JIDAN, 3(2).

Kornides, M. \& Kitsantas, P. (2014) Evaluation of breastfeeding promotion, support, and knowledge of benefits on breastfeeding outcomes. $J$ Child Health Care, 17(3), 264-273

Machfoedz, Ircham, Eko Suryani. 2006. Pendidikan Kesehatan Bagian dari Promosi Kesehatan. Fitramaya, Yogyakarta

Mardiana, L. 2004. Kanker Pada Wanita, Pencegahan dan Pengobatan dengan
Tanaman Obat. Penebar

Swadaya, Jakarta.

Mubarak, I.W, dkk. 2009. Ilmu Kesehatan Masyarakat Teori dan Aplikasi. Salemba Medika, Jakarta.

Mumpuni, Y. 2013. 45 Penyakit Musuh Kaum Perempuan. Edisi I. Rapha Publishing.

Notoatmodjo, S. 2007. Pendidikan dan Perilaku Kesehatan. Rineka Cipta, Jakarta.

Nugroho, T. 2011. ASI dan Tumor Payudara. Cetakan Pertama. Mulia Medika, Jakarta.

Oberhelman, R.A., Potts, K.S., Taub, L.D., Var, C. (2015) What health service support do families need for optimal breastfeeding? An in-depth exploration of young infant feeding practices in Cambodia. IJWH. 7, 249257.

Rasjidi. 2009. Deteksi Dini dan Pencegahan Kanker pada Wanita. Cetakan Pertama, Sagung Seto, Jakarta.

Santosa, Taviv, Y. \& Mayasari, R., 2014. Pengaruh promosi kesehatan terhadap pengetahuan, ( Effect of Health Promotion to Community Knowledge , Attitude and. Buletin Penelitian Sistem Kesehatan, 17, pp.167-176.

Simons-Morton, BG., Green WH., Gottlieb NH., (1995), Introduction to Health 
Education and

Promotion Second edition.

USA: Waveland Press.

Sugandi, A. \& Wahyuni, 2015.

Promosi Kesehatan Dengan

Media Sticker Terhadap

Tingkat Pengetahuan, Sikap

Dan Praktik Penggunaan

Masker Pada Pedagang

Burung di Pasar Depok Kota

Surakarta. IJMS, 2(2)

Sugiyono, 2009. Metode Penelitian

Bisnis. Cetakan Ke-15,

Penerbit CV.ALFABETA.

Bandung.

Sutjipto. 2013. Jumlah Penderita Kanker Payudara Masih Cukup Tinggi. Pustaka Populer Obor, Jakarta. 